\title{
Alexandros Chouliaras, The Anthropology of St Gregory Palamas: The Image of God, the Spiritual Senses, and the Human Body, Studia Traditionis Theologiae 38, Brepols, Turnhout 2020, 243 p., ISBN: 978-2-503-58941-1
}

\section{Ionuţ Biliuță}

The spiritual legacy of St. Gregory Palamas (c. 1296-1357/1359 AD) remains bitterly contested by Western Christians and continues to spark debates between Eastern and Western theology. As the main mouthpiece of hesychasm in the theological arena of late Byzantium, and the defender of monastic Orthodoxy against the Byzantine humanists with their emphasis placed on reason, Palamas established himself as an essential Eastern theologian of the fourteenth century. He was also the leading advocate of the theology of uncreated divine energies emanating from God, helping individuals in their ascetical efforts of self-deification. One area of his theology that received significant attention from both Eastern and Western theologians alike relates to his views regarding theological anthropology and its relationship with the Orthodox teaching concerning ascetical inner renewal. Fr. Alexandros Chouliaras stands on the shoulders of giants (e.g., Meyendorff, Flogaus, Lison, Sinkewicz, Larchet, etc.) when approaching in the present book the anthropology of St. Gregory Palamas.

Based on a doctoral dissertation supervised by two titans in the field of Patristic research, such as Fr. Andrew Louth and Fr. John Behr, and defended successfully at the University of Amsterdam in the Netherlands, the present book invites its readers into the intricate labyrinth of contrasting Patristic perceptions about humanity and its relationship with divinity. Departing from previous scholarship in the field, Fr. Chouliaras chose to analyze Palamas' anthropology not in its entirety but rather by focusing on some relevant texts through the lenses of the image of God in the human person. Accordingly, the image elevates humans over the angels in the divine hierarchy of creation. The author envisages the vital role human senses play in the spiritual growth of the Hesychast monk and Palamas' positive appreciation of the human body in ascetical endeavors. Accordingly, the author shaped his monograph into three significant features. The introduction clearly states the aims of the book that are twofold. On the one hand, the accent falls on the divine image in man comparing anthropology and

\footnotetext{
* Ionuț Biliuță, Gheorghe Șincai Institute for Social Sciences and the Humanities, Romanian Academy, 10A Al. Papiu Ilarian, Tg. Mures, 540074, Mures, Romania, ionut.biliuta@ academia-cj.ro.
} 
with angelology, emphasizing the precedence of man over the angels in the hierarchy of creation.

On the other hand, it stresses the vital role of the human senses and the body in pursuing mystical experiences (p. 2) that render man unique among all divine creations.

Furthermore, it also delineates the main approaches to Palamas' works and theological ideas with a particular highlight on anthropological endeavors (p. 5-16). Moreover, it offers a sophisticated account of the theological context in which he produced his works. Also, the book underlines his active part as the spokesman of the Athonite monks in the Hesychast quarrel with humanists such as Barlaam of Calabria (c. 1290-1348 AD) (among others) and how it impacted his spiritual mindset (p. 16-21).

The second section (p. 35-139) speaks about the divine image inscribed in every man and how the image transforms man into a superior to the angels because of his body. Subdivided into four chapters, the first (p. 35-49) should be read as a tour du force regarding the primary biblical sources and how the biblical vernacular stands as an inspiration for, and subject to reinterpretation, in Palamas' woks. The second chapter (p. 49-87) discusses the continuities and discontinuities between Gregory Palamas' predecessors (the Cappadocians, Maximus the Confessor, John Damascene, Augustine) and his originality. Chouliaras discusses the hypotheses present in secondary literature regarding the possibility that Palamas' undertook vital concepts such as the important role enjoyed by the material body in the spiritual hesychast ascetical practices from St. Augustine of Hippo (354-430 AD).

From a scholarly and analytical point of view chapters, three and four should be considered the hard and seminal core of the section. In chapter three (p. 87-115), Fr. Chouliaras summarizes its primary goal, according to which "man is superior to the angels as far as the image is a concern, but inferior to them" in what concerns the resemblance with God (p. 87). Accordingly, three attributes distance man from the angels as a superior being in what interests the image inscribed into him: the soul's vivifying power, the faculty of governance, and the faculty of sense perception. If someone believes in Palamas' views, then the body men possess over the angels has a human soul that is endowed with the vivifying spiritual power (p. 87). Following Robert Sinkewicz, Chouliaras explains the life-giving ability of the human soul, claiming that without soul's access to divine grace, the human body has no life (p. 88). Following in the footsteps of his illustrious predecessors, Gregory Nazienzus and John Damascene, Palamas considers man as the sole "an initiate of the Trinity" on earth, a position elevating him above the angels. There is a relation of spiritual causality between the human 
soul and the body because the human soul can vitalize the body and, thus, resembling the Trinity, a characteristic of Palamas' theological reasoning that distinguishes him among the Fathers of the Church (p. 91).

Moreover, the author focuses on Palamas' understanding of the faculty of governance that describes man's ability to rule over the created world, an ability linked with the reality of the human body. The importance of human corporeality is unshared by the angels (p. 93). The basic premise upon which Palamas grounds his claim relates to the fact that according to his positive anthropological view, the fall only corrupted the image of God inside man without eradicating it. The same can be said about the faculty of governance, the main attribute of the divine image inside man (p. 94). Following Maximus the Confessor and other fathers, Palamas argues that man's ability to govern creation should lead him eventually in gaining the resemblance with God through deification. This action would usher the deification of creation (p. 96). When speaking of the sense perception of the soul, Palamas identifies a Christological component in human knowledge, which has three parts: the intellectual or intuitive faculty, the rational or discursive faculty, and the faculty of sense-perception (p. 102). Despite the angels, because of these abilities and his body, man can express the spiritual through the rational and represent through arts and science the invisible and making it visible (p. 103). In the last section of the chapter, as a demonstration of man's superiority over the angels through his corporeality Fr. Alexandros Chouliaras brings forth the case of man's participation in the Eucharist. Underlining the eschatological character of human involvement through his body to the divine mysteries, Palamas, probably unaware of John Damascene before him, claims that man can achieve the resemblance with God and be superior to the angels (p. 110).

Chapter four (p. 115-19) stands as a short excursus about the superiority of angels over men in what concerns the resemblance with God. While men possess more likeness to the image of God because of the human soul, and can achieve the likeness with God as angels through askesis and deification, the Byzantine theologian also says angels possess, up to a point, the image of God (p. 124). In what concerns the body, "Palamas shows great sympathy for and recognition for the human body. This implies that he fully recognizes and respects, even exalts, all the activities carried out employing the body: the quest of science for knowledge, biological needs, sexual relationship, etc. Palamas is a very humane ascetic, one that fully accepts the psychosomatic union that constitutes the human being. Nevertheless, he underlines that all these bodily actions have to be exercised in Christ, and in the way, the Church teaches, so as to preserve in the believer the image of God and guide him towards the restoration of the likeness." (p. 121). 
The second section of the book approaches several theological topics. Human knowledge of the divine through reason and spiritual senses, the relation between human corporeality and deification, and how spiritual senses effectively mediate and facilitate the ascetical efforts of the man looking for his deification are but a few from Palamas' main concerns. Referring to these, Fr. Chouliaras expresses his aim quite bluntly: "the human body has the most significant role in his theology" of human senses (p. 129).

While chapter five (p. 129-45) represents the contextualization of Palamas' main ideas about the human senses, the core chapter of the section should be considered chapter six which describes intellectual perception (p. 145-165). In his theological endeavors of defining the human intellect, the Byzantine theologian draws on two important hypotheses. First, the intellect has two faculties, namely the power of intellection related to intelligence (dianoia) and "the power of super-intellectual union." (p. 146) Second, "the union with God" transcends human intelligence and knowledge being a mystery of the personal encounter between God and man. (p. 146). Furthermore, Alexandros Chouliaras reconstitutes the Byzantine father's arguments in identifying four reasons: the fact that the perception of spiritual and divine good transcends natural senses and the intellect is the first faculty of the soul to receive the divine goods. Also, the human intellect resembles the divine intellect and the body because of its communion with the human intellect is also elevated. Furthermore, the power of the Holy Spirit is perceived through the eyes of the soul for considering the intellect as the meeting place between God and man (p. 147). In Palamas' opinion, there are two reasons that the intellectual perception of God should be called "perception" because man senses his experiences through intellectual perception. He feels already that he experienced something essential. Proving the validity of his claims regarding the spiritual perception of the divine at the level of the human intellect, Gregory Palamas uses the example of the experience of the divine light/grace and, therefore, how the knowledge of God can be reached through spiritual senses. According to Chouliaras, in the Palamite corpus, "through the spiritual senses man comes to a real knowledge of God, a real sensing of the divine. Therefore, it could be said that man 'possesses' God." (p. 151). The book answers the correlation between spiritual and physical senses because these senses seem to coordinate with one another in the encounter with divine grace. (p. 151) Following Plato and the distinction between God's essence and its energies/works, Palamas argues that the intellect can see the light because he is also light at some level. If someone would speak about God's grace, then man would see the light of God, but not his essence, instead through the synergy with the Spirit of God, the works and 
activities of God in the creation. (p. 153) This leads the reader to the core of the Hesychast debate. As an advocate of the ascetical school of hesychasm, he clearly states that man can see more divine light as he reaches a greater degree of communion with divine grace. He reasserted his dominion over the passions through askesis and achieved humility through obedience to spiritual guides. (p. 157). No wonder that Palamas considers that the light that shined on Mount Tabor over Jesus' disciples was the divine light of Paradise, and they experienced it at an intellectual level, with their spiritual and physical senses. (p. 161).

A significant synthesis in the field of Patristic studies, the book of Alexandros Chouliaras preserved its originality. The importance allotted to the Augustinian influence in Gregory Palamas' works, the privileged status of the human body in deification, and the sensible and rational knowledge of the divine should all count as original developments in the field of Palamite and Patristic studies. Furthermore, contrary to some voices, Fr. Chouliaras' approach to St. Gregory Palamas is an integrative effort to underscore the Byzantine father's contribution as a participant in the chorus of Western and Eastern doctors Christendom. Fr. Chouliaras should be praised for constantly underlining throughout his narrative the fact that Byzantine theology in the fourteenth century tended to be a space of transnational and trans-confessional dialogue.

While richly supported by primary and secondary sources, the present book also has some flaws that need rapid remedy in a second edition. First, the reader, whether a specialist or an ignorant, has real problems in following the arguments the author intends to make throughout the book because of the lack of narrative flow. At present format, it appears that what the reader finds when opening the book is more of a raw doctoral dissertation eager to make a valid argument, rather than a book that also has a narrative structure. Second, it would be advisable for the author to have more courage in opening Palamas' anthropology to voices and approaches from other fields of theology (systematic theology, ethics, bioethics) and sciences.

Adorned with a lavish collection of primary and secondary sources, the book by Fr. Chouliaras should be a must-read for theologians, students in theology, scholars in religious studies, and simple believers. It should become mandatory reading in graduate and undergraduate courses in Systematic Theology, Patristics, Christology, Ecumenism, Church History. 